\title{
Almaty 2007
}

\author{
By Ron Holloway
}

Fall 2007 Issue of KINEMA

\section{$4^{\text {th }}$ EURASIA INTERNATIONAL FILM FESTIVAL ALMATY}

\section{The Saga of Chingiz Aitmatov}

When Chingiz Aitmatov went onstage in the spacious Palace of the Republic in Almaty (former Alma-Ata) at the closing gala of the Fourth Eurasia International Film Festival (23-29 September 2007) to receive an honorary award from the Kazakh government, he was greeted with a standing ovation. Indeed, the applause was well deserved. For the 78-year-old Kirghiz writer-diplomat is revered throughout Central Asia not only as a gifted storyteller, whose heart-rending novella Jamila (published in 1958) was praised by Louis Aragon as "the world's most beautiful love story," but also as the first Kirghiz Ambassador to Luxembourg and the European Union in Brussels. Moreover, during the high-water mark of the Khrushchev "thaw" (1956-65), when Chingiz Aitmatov was appointed head of the Kirghizfilm Studio in Frunze (today Bishkek), he fostered there a path-breaking "director's cinema" that helped to revolutionize Soviet cinematography altogether. How Chingiz Aitmatov accomplished this rather extraordinary feat still boggles the imagination today. For the newly appointed studio head, however, it simply meant sustaining a fading nomadic culture while fostering a native film tradition.

Upon receiving the 1963 Lenin Prize for Literature for his Tales of the Mountains and the Steppes, and backed by a film studio ready-and-willing to do his bidding, Chingiz Aitmatov had invited a talented 22-year-old student from the Moscow Film School (VGIK) to direct the studio's first film production. Larisa Shepitko had sent him a script based on his own Camel's Ear story in the Tales of the Mountains and the Steppes collection. Her Heat (1963), upon completion, seemed assured of instant success with the Central Asian public, although hardly with the Soviet censors in Moscow. But as the film's responsible producer, Aitmatov had another card up his sleeve. Recognizing that Heat had challenged the then sacrosanct principles of socialist realism, he arranged for the film to be shown first at the 1963 Festival of Central Asian Films in Dushanbe, the capital of neighbouring Tajikistan. There, as it turned out, a release certificate was fortunately granted and the film cleared for exhibition throughout the Soviet Union. Recognition in Dushanbe, in turn, encouraged Kirghizfilm to enter Heat in 1964 at the First All-Union Soviet Film Festival in Leningrad, where it was awarded the Prize for Best Direction. That same year, Heat was invited to the Karlovy Vary International Film Festival, where both the film and Kirghiz cinema were hailed as a phenomenon on the world film stage.

Following the success of Larisa Shepitko's Heat at the Leningrad All-Union festival, Andrei MikhalkovKonchalovsky, her colleague at the Moscow Film School, also journeyed to Kyrgyzstan to direct his first feature film. And, of course, Konchalovsky's The First Teacher (1964) was based on another Chingiz Aitmatov story, published under the same title in 1962. When the film finally received Soviet permission to be screened at the 1966 Venice International Film Festival, Natalya Arinbasarova in the role of the "first teacher" was awarded the Volpi Prize for Best Actress. It was the second major Soviet film success at Venice, following a share of the Golden Lion awarded to Andrei Tarkovsky's Ivan's Childhood in 1962. Thus, although the Khrushchev "thaw" was finished, a core of "Young Soviet Directors" were to become a catchword at international film festivals - thanks to the foresight of writer-producer Chingiz Aitmatov.

\section{"Kazakh New Wave" Remembered}

Eurasia Almaty 2007 closed on another high note at the Palace of the Republic, this time prompted by a VIP address by Adilbek Zhaksybekov (sometimes spelled Dzhaksybekov), Head of the Presidential Administration under Kazakh President Nursultan Nazarbayev. From now on, Zhaksybekov announced, the Eurasia Film Festival would be held annually, instead of biannually since its founding in 1998. And he added: "We believe in a great future for the Eurasia film festival and wish our Kazakh cinematography to develop as rapidly as our political and economical stability." One has to take the Presidential Administrator at his word, for among the political hats worn by Adilbek Zhaksybekov over the past few years are: Mayor of Astana (2002), Board Chairman of the Islamic Development Bank (2003), Minister of Industry and Trade (2004), Chairman of Information and Communications Agency (2004), and (in August of 2007) President of the Soccer Federation 
of Kazakhstan. Most important of all for the struggling Kazakh film industry, Zhaksybekov (born in 1954) had studied film economics at the All-Union State Cinematography School (VGIK) in Moscow and began his career in the 1980s in the State Cinematography Office of the Soviet Kazakh Republic in Almaty.

It was during this time that the "Kazakh New Wave" had burst like a comet upon the international festival scene. In 1984, while Sergei Solovyov, a Moscow-based Russian director, was shooting The Wild Pigeon in Kazakhstan, he invited young Kazakhs from his film crew to attend his Master Class at the Moscow Film School (VGIK). Among these youngsters was Rashid Nugmanov, whose first feature film, The Needle (1988), was seen by an estimated 25 million across the Soviet Union - an incredible box office hit by any standard. Independently produced at the Kazakhfilm Studio, this avant-garde, action-gangster, rock-anddrugs feature starred underground pop-star Victor Tsoi with music on the soundtrack played by his band. Shortly thereafter, at the 1989 Moscow film festival, other films by Kazakh directors were screened, and the "Kazakh New Wave" was coined by visiting critics, and invitations from abroad immediately followed. In 1990, Rashid Nugmanov, the newly elected First Secretary of the Union of Kazakh Filmmakers, attended the Sundance festival. Shortly thereafter, just as Kazakhstan was declaring its national independence in 1991, a Kazakh film retrospective was programmed at the Centre Pompidou in Paris.

Unfortunately, the "Kazakh New Wave" lasted a short ten years, from 1984 to 1994. During this time, however, international audiences became well acquainted with the diverse talents of the directors in the movement. Darezhan Omirbaev, critic-editor for the Almaty-based New Film journal, was recognized as a genuine auteur after the international success of his minimalist short, July (1988). His first feature film, Kairat (1991), the story of a young man from a village who faces loneliness and despair in Almaty, was awarded the Silver Leopard at the 1992 Locarno festival. Abai Karpikov also portrayed the pessimism of Kazakh youth in Little Fish in Love (1989). Serik Aprimov took the pulse of the decaying Soviet empire in The Last Stop (1989). Amir Karakulov's A Woman Between Two Brothers (1991) won critical praise as a sophisticated psycho-drama. And Ardak Amirkulov's The Fall of Atrar (1991) broke new ground as the first genuine Kazakh historical epic. National independence, however, brought with it increasing government interference at the Kazakhfilm Studio. Rashid Nugmanov just managed to finish The Wild East (1993) before emigrating to France. A year later, in the summer of 1994, only one film was in production at Kazakhfilm, while three projects at the studio had been halted midway through production. Still, the mystique of the "Kazakh New Wave" has lived on in the work of directors who found co-production support abroad in France and other western European countries.

\section{Highlights at 2007 Eurasia Almaty}

Almaty is a boom town. Buoyed by extensive oil and gas reserves and stabilized by agricultural products and grain exports, the Almaty well-to-do are anything but reluctant to celebrate the good life. During the week-long Eurasia festival a trio of massive festive banquets were held to honour VIP guests and government officials flown in from the Astana capital. The French delegation was particularly prominent, led by Gerard Depardieu and Sophie Marceau. Film directors, producers, and actors from neighbouring Central Asian countries were also highly visible. Screenings were held in the multiplex at the mammoth Silk Way City mall, the Caesar theatre chain scattered across the city, the Palace of the Republic, and Dom Kino (the House of Cinema headquarters of Kazakh directors). The 150-page catalogue in three languages (Kazakh, Russian, English) also spotlighted the support given by over 50 sponsors, the most prominent of which was the festival's General Sponsor, the "Atameken Holding" Joint Stock Company.

Artistic Director Gulnara Abikeyeva assembled a solid program of 15 entries for the International Competition of Asian and European Films, with purses for winners totalling around $\$ 50,000$. Another 12 entries competed for laurels in the Competition of Central Asian and Turkic Films. Directorial retrospectives honoured Taiwan's Tsai Ming-Lang, Greece's Theo Angelopoulos, Kazakhstan's Mazhit Begalin, and Kazakh Animation (celebrating its $40^{\text {th }}$ anniversary). These, in addition to an Out-of-Competition sidebar featuring highlights from recent international film festivals. Of particular importance to visiting critics was a wellattended roundtable on the current status of Central Asian cinema conducted by Gulnara Abikeyeva. Here, productions in neighbouring Central Asian countries were discussed at some length, with European visitors taking notice of new Central Asian film festivals that bode well for the future. Critic Gulbara Tolomushova heads the progressive Bishkek film festival in Kyrgyzstan, a short four-hour driving distance from Almaty. And filmmaker Safar Hadkodov programs the equally vital Dushanbe film festival in Tajikistan. 
Kazakh entries were stand-outs at this year's Eurasia film festival. In the International Competition the Special Jury Prize was awarded to Darezhan Omirbaev's Shuga, a free-flowing adaptation of motifs in Tolstoy's Anna Karenina to a contemporary Kazakh milieu. Often cited as the "Robert Bresson of Central Asian Cinema," Darezhan Omirbaev's minimalist style has guaranteed him continual French co-production support over the years. Ainur Turganbaeva gives a remarkable performance as the tragic heroine Shuga, a married woman from Astana who falls fatally for a young suitor while trying to reconcile her brother's marriage problems in Almaty. The Grand Prize in the Central Asian and Turkic Competition was awarded to Abai Kulbai's Strizh (Swift), a portrait of a young girl who struggles with forces beyond her control a drunken stepfather, a pregnant mother, drugs and violence at school - to find her place in an ice-cold, impersonal, and uncaring Almaty. When Abai Kulbai accepted his prize in the Palace of the Republic, he requested that his mentor in a director's workshop at the Almaty Academy of Arts join him onstage for the honour - Ardak Amirkulov, one of the key figures in the "Kazakh New Wave" of yesteryear.

Bahman Ghobadi's Niwemung (Half Moon) was deservedly awarded the Grand Prize for Best Film in the International Competition. Given the portfolio of the festival, Half Moon is "Eurasian" to the core - an Iranian-French-Austrian-Iraqi road movie co-production. When Mamo, an old and venerated Kurdish musician living in Iran, announces to his ten sons that he wants to give one final concert in his native Kurdistan quarter of Iraq, they immediately join the stubborn old man on his journey in a dilapidated bus - even though they suspect that his visa papers are hardly in order. Along the way, the musicians stop to pick up a female singer in an isolated village, a decision that can only lead to more trouble - for Iranian women are not allowed to sing in public before an audience with men. Add to these dilemmas a premonition of death (the half-moon in the old man's dreams), and you have a spellbinding Iranian-Iraqi border movie you will not easily forget.

\section{References}

\section{EURASIA ALMATY AWARDS}

\section{International Competition}

Grand Prix - Best Film

Niwemung (Half Moon, Iran-France-Austria-Iraq), dir Bahman Ghobadi

Best Director

Alexei Popogrebsky, Prostyje veshchi (Simple Things, Russia)

Special Jury Prize - ex aequo

Shuga (Kazakhstan), dir Darezhan Omirbaev

Foster Child (Philippines), dir Brillante Mendoza

Best Actor

Leonid Bronevoy, Prostyje veshchi (Simple Things, Russia), dir Alexei Popogrebsky

Best Actress

Fan Bing Bing (Bingbing Fan), Ping guo (Lost in Beijing, China), dir Yu Li (Li Yu)

\section{Central Asian and Turkic Competition}

Grand Prix - Best Film - ex aequo

Strizh (Swift, Kazakhstan), dir Abai Kulbai

Boz salkyn (Light Cool, Kyrgyzstan-Kazakhstan), dir Ernest Abdyzhaparov

Best Director

Fatih Haciosmanoglu, Beton yastık (Concrete Pillow, Turkey)

Special Jury Prize

Not awarded 
Best Actress

Dinara Kashaganova, Kine (Sin, Kazakhstan), dir Bolat Sharip

Atameken Holding Award - International Competition

California Dreamin' (Romania), dir Cristian Nemescu

Netpac Award - Central Asian and Turkic Competition

Strizh (Swift, Kazakhstan), dir Abai Kulbai

Investment in Asian Cinema Prize

Nurmahan Zhanturin, actor (posthumously)

Investment in World Cinema Prize

Jacqueline Bisset, actress

\section{Author Information}

Ron HOLLOWAY (1933-2009) was an American critic, film historian, filmmaker and correspondent who adopted Europe as his home in the early fifties and spent much of his life in Berlin. He was an expert on the study of German cinema and against all odds produced, with his wife Dorothea, the journal German Film, keeping us up-to-date with the work of directors, producers and writers and the showing of German films around the world.

In 2007, Ron Holloway and his wife were awarded the Berlinale Camera Award. Ron also received the Bundesverdienstkreuz (German Cross of Merit), Polish Rings, Cannes Gold Medaille, the American Cinema Foundation Award, the Diploma for Support of Russian Cinema and an honorary award from the German Film Critics' Association.

Ron was also a valued contributor to Kinema for the past fifteen years. 